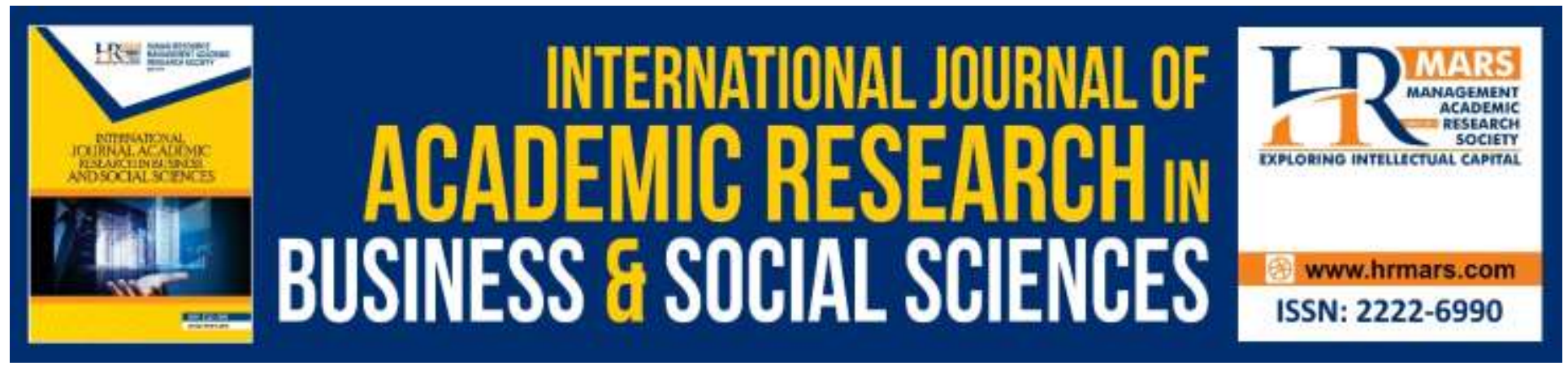

\title{
Determinants of Shopping Mall Patronage among Consumers in Enugu Metropolis
}

Okoro, Deborah P, Okolo, Victor O, Mmamel, Zita U

To Link this Article: http://dx.doi.org/10.6007/IJARBSS/v9-i11/6557

DOI: 10.6007/IJARBSS/v9-i11/6557

Received: 21 October 2019, Revised: 30 October 2019, Accepted: 08 November 2019

Published Online: 26 November 2019

In-Text Citation: (Okoro, Okolo \& Mmamel, 2019)

To Cite this Article: Okoro, D. P., Okolo, V. O., Mmamel, Z. U. (2019). Determinants of Shopping Mall Patronage among Consumers in Enugu Metropolis. International Journal of Academic Research in Business and Social Sciences, 9(11), 400-420.

Copyright: (c) 2019 The Author(s)

Published by Human Resource Management Academic Research Society (www.hrmars.com)

This article is published under the Creative Commons Attribution (CC BY 4.0) license. Anyone may reproduce, distribute, translate and create derivative works of this article (for both commercial and non-commercial purposes), subject to full attribution to the original publication and authors. The full terms of this license may be seen at: $\underline{\text { http://creativecommons.org/licences/by/4.0/legalcode }}$

Vol. 9, No. 11, 2019, Pg. 400 - 420

http://hrmars.com/index.php/pages/detail/IJARBSS

JOURNAL HOMEPAGE

Full Terms \& Conditions of access and use can be found at http://hrmars.com/index.php/pages/detail/publication-ethics 


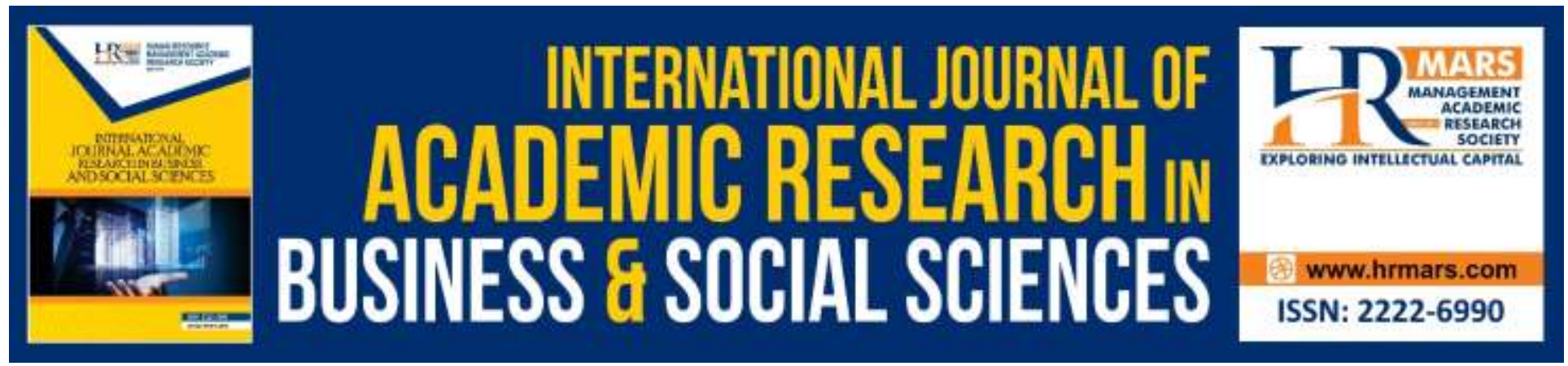

\title{
Determinants of Shopping Mall Patronage among Consumers in Enugu Metropolis
}

\author{
Okoro, Deborah P, Okolo, Victor O \\ Department of Marketing, University of Nigeria Nsukka, Enugu Campus. \\ Mmamel, Zita U \\ Department of Marketing, Institute of Management and Technology, Enugu. \\ Email: victor.okolo@unn.edu.ng
}

\begin{abstract}
The aim of this study is to determine those factors that influence shoppers to shop in malls in Enugu metropolis. Specifically, the study sought to examine the influence of distance on shoppers' patronage of shopping malls in Enugu metropolis, evaluate the influence of convenience on shoppers' patronage of shopping malls in Enugu metropolis, to ascertain the influence of customer services on shoppers' patronage of shopping malls in Enugu metropolis, determine the effect of socialisation on shoppers' patronage of shopping malls in Enugu metropolis and evaluate the influence of exploration on shoppers' patronage of shopping malls in Enugu metropolis. Survey method was adopted for this study. Adults 18 years and above were the target population. A sample size of 596 was used for the study. Data was gathered using a well-structured questionnaire. Five hypotheses were tested using Structural Equation Modeling (SEM). The test was run on AMOS version 25.0 with maximum likelihood estimation. Findings revealed that distance does not have a significant influence on shoppers' patronage of shopping malls in Enugu metropolis. In contrast, convenience had a significant influence on shoppers' patronage of shopping malls in Enugu metropolis. Also, customer Service does not have a significant influence on shoppers' patronage of shopping malls in Enugu metropolis. Socialization had a significant influence on shoppers' patronage of shopping malls in Enugu metropolis. Lastly, exploration had a significant influence on shoppers' patronage of shopping malls in Enugu metropolis. The study concludes that distance and customer service are not major factors that stimulate shoppers' patronage. Factors like convenience,socialization and exploration are important factors determining shoppers' patronage in Enugu metropolis. The study recommends that the management of the shopping malls should direct their resources toward constant improvement on the mall facilities that attract shoppers to the mall.
\end{abstract}


INTERNATIONAL JOURNAL OF ACADEMIC RESEARCH IN BUSINESS AND SOCIAL SCIENCES

Vol. 9, No. 11, November, 2019, E-ISSN: 2222-6990 @ 2019 HRMARS

Keywords: Patronage, Shopping Mall, Distance, Convenience, Socialization, Exploration, Customer Services.

\section{Introduction}

The decision to patronize a mall usually starts with a set of characteristics or attributes that consumers consider important. Consumers use these attributes to determine which mall can cater to their needs (Hassan, Muhammad and Bakar, 2010). One can analyze mall shopping patronage as repeat visits or mall loyalty and as a function of actual buying behavior. That is purchase frequency or purchase absence. When customers are dissatisfied with the features of a shopping mall or the quality and variety of commodities, they will buy fewer or no items resulting in no waste of time. Therefore, one can view purchasing frequency as an indication of mall patronage (Rousseau and Venter, 2014).

While shopping, Kasnaeny, Sudiro, Hadiwidjojo and Rohman (2013) note that customers are driven by the behavior that leads to choosing a place that responds to their wishes. The choice is basically on the stimulation that is triggered by the image of the company that will prop the form of patronage behavior. The purpose of patronage is to get a customer to shop at a mall, willingness to recommend to others and a tendency to spend time in the shop. Behavioral intention is a conscious effort from someone who will guide and determine spending decisions such as the selection of shops and a willingness to switch brands (Chang and Luan, 2010). Mathwick, Malhotra and Rigdon, (2001) equally state that the intention of patronage is defined as the customer wishes to consider, recommend, or make purchases from retailers in the future, the desire to buy from it, and the willingness to make referrals to others in the future.

The shopping mall has become a place to locate and purchase goods. Itis also known as a cultural hotspot where people of all ages can come to interact and get a paramount deal out of bargaining (Coleman, 2007). Shopping is becoming increasingly popular throughout the world leading to increased development of malls (Muange, 2014). Similarly to marketplaces, modern shopping malls have become important centres of social life, serving commercial, entertaining, recreational, cultural, educational, integration and socialising purposes (Kochaniec, 2011). However, the shopping malls of today are greatly influenced by technology; the use of new building materials gives shopping malls new forms and overall looks (Iliyasu, 2011).

Mall patronage like mall choice or preference is a result of a consumer's evaluation of one mall being superior to others based on their experience (Thang and Tan 2003). There are various dimensions to mall patronage behavior. They include patronage intention, frequency of visits, time spent, number of items bought, shopping enjoyment, satisfaction, repeat purchase, money spent, and share of wallet (Paswan, Pineda and Ramirez, 2010). It is expected that positive consumer perceptions of a mall on both functional and psychological factors of importance to them will increase the likelihood of the mall being chosen by the consumer (Paswan et al. 2010). Mall patronage or preference is determined by so many factors like distance, convenience, price, quality of customer services, socialization and exploration. Shopping malls are the answer to the 
needs of contemporary clients who have less time but more information and requirements about shopping, who expect a comprehensive offer in pleasant surroundings and perfectly combine shopping with other activities (Heffner and Twardzik, 2014). This study intends to look into the determinants of shopping mall patronage among shoppers in Enugu metropolis.

\section{Statement of the Problem}

Over the years, shoppers in Enugu metropolis have been accustomed to shopping in traditional marketplaces such as Ogbete main market, Kenyatta market, Artisan market, New market and neighbourhood stores. However, the emergence of shopping malls in the retailing landscape in Nigeria particularly in Enugu metropolis seems to have dramatically jolted shopping destination choices among shoppers. For instance, a cursory observation demonstrates increasing traffic of shoppers of different ages to the malls. Despite the rapidly growing interest in mall shopping among shoppers in Enugu metropolis, minimal research attention has been directed in this domain to deepen and possibly broaden understanding regarding those factors like distance, convenience, customer services, socialization, and exploration among others that influence shoppers to shop in malls. These variables as indicated above need to be investigated to see how they affect shopping mall patronage among shoppers in Enugu metropolis.

Several studies have been conducted in these areas in other countries (Wong, NG, Wong and Wong 2012; Kumar and Thakur, 2014) though, findings in those studies may not apply to Nigeria; particularly Enugu metropolis due to difference in culture and development. Also, previous studies were characterised by inconsistencies in results leading to unresolved debates (Basher, 2012). This further demonstrates the need for a holistic investigation to contribute to the discourse and sieve the inconsistencies that characterise previous studies using Nigeria-based data. Thus, the limited empirical research regarding the drivers of mall shopping behavior in Enugu metropolis at the moment has arguably created a knowledge vacuum that calls for evidence-based research to address the gap.

\section{Objectives of the Study}

The main objective of this study is to understand those factors that influence shoppers to shop in malls in Enugu metropolis. This broad objective is broken into the following specific objectives: 1. To examine the influence of distance on shoppers' patronage of shopping mall in Enugu metropolis.

2. To evaluate the influence of convenience on shoppers' patronage of shopping mall in Enugu metropolis.

3. To ascertain the influence of customer services on shoppers' patronage of shopping mall in Enugu metropolis.

4. To determine the effect of socialisation on shoppers' patronage of shopping mall in Enugu metropolis.

5. To evaluate the influence of exploration on shoppers' patronage of shopping mall in Enugu metropolis. 


\section{Research Hypotheses}

Following the objectives of the study and research questions, the following hypotheses were stated for testing:

1. Distance does not have any significant influence on shoppers' patronage of shopping malls in Enugu metropolis.

2. Convenience does not have any significant influence on shoppers' patronage of shopping malls in Enugu metropolis.

3. Customer services do not have any significant influence on shoppers' patronage of shopping malls in Enugu metropolis.

4. Socialization does not have any significant effect on shoppers' patronage of shopping malls in Enugu metropolis.

5. Exploration does not have any significant influence on shopper's .patronage of shopping mall in Enugu metropolis.

\section{Significance of the Study}

This study will be beneficial to the marketing managers, this is because the findings of this study have a great potential for determining marketing strategy formulation and choices geared towards competitiveness in the retail landscape currently dominated by traditional marketplaces. The findings will equally help mall developers regarding future mall buildings and designs. Finally, the findings in this study may serve as a veritable repository for the academia.

\section{Scope of the Study}

The scope of this study is restricted to determinants of shopping mall patronage among shoppers in Enugu metropolis. The study centres on distance, convenience, customer services, socialization and exploration.

\section{Review of the Related Literature}

This chapter explores the literature related to shopping mall patronage among shoppers in Enugu Metropolis.

\section{Conceptual Review of Shopping Mall}

The idea of shopping mall started in the United States and grew rapidly in the 1950s. This concept was then expanded to other countries of the world (Wai, 2009). According to Idoko, Nkamnebe and Okoye (2017), a shopping mall is a retail model that is planned, built, and centrally managed as a single unit housing independent retailing outlets with an identifiable anchor tenant. In their contribution, Wee and Tong (2005) define a shopping mall as a group of retail and other commercial establishments that is planned, designed, developed, owned and managed as a single property. However, Warnas, Bennison and Davies (2005) define the shopping mall as a planned retail development comprising various retail outlets that are under one freehold ownership and managed and marketed as a unit. 
Shopping mall is a collection of independent retail stores, services, and a parking area which is conceived, built, and maintained by a separate management firm as a unit (Bellis, 2011). Levy and Weitz (2007) and Lambert (2006) observe that shopping mall is a cluster of stores located in a single building, planned, designed, and built for retailing and retail-related activities. They are managed as a single unit by institutional centre management.

A shopping mall is an enclosure having different formats of in-store retailers all under one roof. Mall location, mall access parking spaces, product assortment, pricing level, service quality and promotional activities are the elements that affect mall image positively (Ou, Abratt and Dion 2006; Hira and Rasheed, 2012 ). Shopping malls are the most glorious places these days with their attractive shops and a wide variety of people where people spend their weekends to relax and shop. With the changing tastes and preferences of customers, shopping malls extend a global impact across metros, cities and towns (Mohamad, Katheeri and Salam, 2015). Shopping is considered fulfilling three fundamental human needs such as autonomy, competence, and relating to others (Tauber, 1972). Satisfaction of these needs plays an important role in overall subjective well-being or happiness (Deci and Ryan, 2002).

\section{Distance}

The closer a shopping mall is to where a consumer lives or works the more convenient it should be for him/her to shop there (Reimers, and Clulow,2009) In the process of seeking to maximise value, consumers may visit a more distant mall if it offers better entertainment or convenience opportunities. Out-of-town malls seek to compensate for their outlying location by offering consumers other forms of convenience such as one-stop shopping and easier access and parking and greater ambience. Handy and Clifton (2001), note that shopping location enhances the quality of life of consumers such that they do not have to travel long distances toshop in shopping malls. Kotler and Armstrong (2004) opine that locations of retailers must be accessible to the potential target group of customers. A far distance has a negative effect on the selection of a retail store by reducing the frequency of customers visiting a store (Hansen and Solgaard, 2004).

\section{Convenience}

Operating hours and time are taken to reach the mall are one of the major criteria which the consumers look for while choosing in a shopping mall. Consumers usually prefer a mall that is closer to their house. Loudon and Bitta (1993) also discover that consumers seek high convenience; they dislike spending time and effort finding parking space, department or a particular product. They also found that convenience is also an important criterion for customers who are either visiting or making a purchase in a mall occasionally. Consumers are getting more and more inclined towards aimpulsive buying for their complete shopping desire (Kaufman, 1996). A convenience orientation is a key benefit that shoppers seek in the modern environment. In this sense, consumers' perceptions of convenience include opening hours, location and parking which have a positive influence on their satisfaction with the service (Berry, Kathleen and Dhruv, 2002). Consumers' perceived expenditure of time and effort interacts to influence their perceptions of service convenience and retail facilities can be designed to affect those time and 
effort perceptions. In addition to a convenient location, other convenience incentives provided by retailers, such as longer operating hours or ample parking, can attract consumer patronage to a mall (Hansen and Deutscher, 1978).

Convenience or accessibility can be divided into two namely macro and micro-accessibility. While macro-accessibility concerns access road to the mall and the nearness of the mall to the customer's place of work or residence. Micro accessibility refers to the parking facilities and ease of navigation/ traffic within the shopping mall in Ahmad (2012).

\section{Customer Service}

Satisfied customers are defined as the number of customers or proportion of total customers; whose reported experience with a firm, its products, or its services exceeds specified satisfaction levels (Farris, Neil, Philip and David, 2010). According to Kim, Park and Jeong (2004), customers' satisfaction is customer's reaction to the state of satisfaction and customer's judgment of satisfaction level. Wong et al. (2012) observe that there is a relationship between shopping mall attributes and customer satisfaction. Manana (2009) also suggest that consumers evaluate the mall by product and different features of mall such as location, employees and atmosphere. Asamoah (2012) opines that retailers are expected to offer good measures that will entice consumers to visit and patronize their shops. Most importantly, the retailers try to create a strong rapport with the customers such that they will continue to buy frequently from their shops, instead of other competitors. Successful retailers, in this regard, are greatly concerned about customer retention. Customer retention could be described as the activity that is performed by organisations to create lasting relationships with customers to reduce customer defections (Jobber, 2001).

When a consumer is ready to make a buying decision, individual retailers are expecting to be chosen over other service providers. On the other hand, other service providers will also be ready to provide solutions to customers' needs and wants (Abrams, 2008). Therefore, what makes a customer select a particular retailer over others and why consumers choose one shop over another is quite difficult to ascertain. Consumers themselves do not have much idea as most of them are of the view that they visit a particular shop because the goods or services are better but, because they trust the source that gave them the information about the shop. Retailers should endeavour to get emotionally linked with consumers. It is a matter of establishing feelings of intimacy, affection, and trust with the prospective customers (Berry, 2001). Consumers prefer buying from retailers who share their emotions with them; retailers should connect emotionally with customers by making them feel at home, telling them the truth, impressing them, and showing love and gratitude (Rust and Anthony, 1993). Customers Service refers to the identifiable, but sometimes intangible activities undertaken by a retailer in combination with the fundamental goods and services it sells. It has a strong impact on the whole retail experience. Among the factors comprising a customer service strategy are store hours, parking space, shopper friendliness of the store layout, credit acceptance, salespeople, amenities such as gift wrapping, restrooms, employee politeness, delivery policies, the time shoppers spend on checkout lines, and customer follow up. Loudon and Bitta (1993) also observe that most of the 
people prefer to shop at the location where the behavior of the employees towards them is cordial and courteous.

\section{Socialization}

Tiwari and Abraham (2010) observe that shopping offers an individual an opportunity to socialise. It often result in meeting up with old friends or new acquaintances. The opportunity of socialisation is an important factor related to the shopping experience. Babin (1994) opines that a consumer may have shopping motives that influence shopping behavior other than the acquisition of goods. These non-functional reasons for shopping include social motives, such as the desire to interact with salespeople and other shoppers and the chance to organise meeting with friends. Malls are also civic centres and the heart of entertaining and social activities ( $\mathrm{Ng}$, 2003). Social interaction is often used to understand how youths acquire consumer related attitudes and skills through the influence of families and friends. As individuals interact frequently and directly as a cohesive group, similar attitudes and values are developed. Idoko et al. (2017) also opine that shopping malls provide an uncommon platform for social interaction across demographics which are rarely available at home or in other retail outlets. Social activities are activities that involve human interaction and include strolling, social meetings, sitting in public places, speaking with strangers and watching other shop (Makgopa, 2016).

\section{Exploration}

Shopping as a leisure activity is the subject of exploration (Tosun, Temizkan, Timothy and Fyall, 2007). Consumers happily combine shopping with vacations, holidays, and trips during their work-related travel (Ghaddar and Brown, 2005). Graham (1988) opines that mall shopping has become an expression of personal values. In many instances, the shopping mall is a social and recreation meeting place attracting youngsters and seniors. Malls usually have an avenue for special events, exhibitions, exercising, shows, and entertainment (Poe and Courter, 1996). Consumers are fun-seekers always on the move for something new. The introduction of malls as an alternate retail option seems to provide shoppers with an opportunity to look for modern items or study about other people's way of life (Idoko et al., 2017). Shoppers who are primarily driven by materialistic tendencies and compulsive consumption explore malls frequently and even enjoy spending time in malls (Telci, 2013). Exploration brings out consumer's quest for variety, new improvements in technology, new ways of doing things and updated products (Rupesh and Anish, 2010).

\section{Theoretical Review}

The Theory of Reasoned Action (TRA) can be best used to describe the factors determining increased patronage of shopping malls theoretically. This theory originates from the field of social psychology. Martin Fishbein and Icek Ajzen developed the theory as an improvement upon Information Integration theory (Ajzen and Fishbein, 1980; Fishbein and Ajzen, 1975). The theory describes the link between beliefs, attitudes, norms, intentions, and behaviors of individuals. According to the theory, a person's behavior is determined by his/her behavioral intention to 
perform it. That is, a person's patronage of big shopping malls in Enugu metropolis as opposed to shopping at traditional marketplaces such as Ogbete main market and neighbourhood stores which people are accustomed to before is a function of the Perso's behavioral intention. This intention is itself determined by the person's attitudes and his subjective norms towards the behavior. Fishbein and Ajzen (1975) define the subjective norms as the person's perception that most people who are important to him think he should or should not perform the behavior in question (i.e. to shop at the big malls or not). Also, Fisbbein and Ajzen (1975) define the attitude of a person towards a behavior (shopping at big malls) as being determined by his beliefs on the consequences of this behavior, coupled with his evaluation of these consequences. Beliefs are defined by the person"s subjective probability that performing a particular behavior will produce specific results. In other words, the TRA model suggests that external stimuli influence attitudes by modifying the structure of the person's beliefs. Moreover, behavioral intention is also determined by the subjective norms that are themselves determined by the normative beliefs of an individual and by his motivation to comply with the norms. This theory is better illustrated in Figure 1.

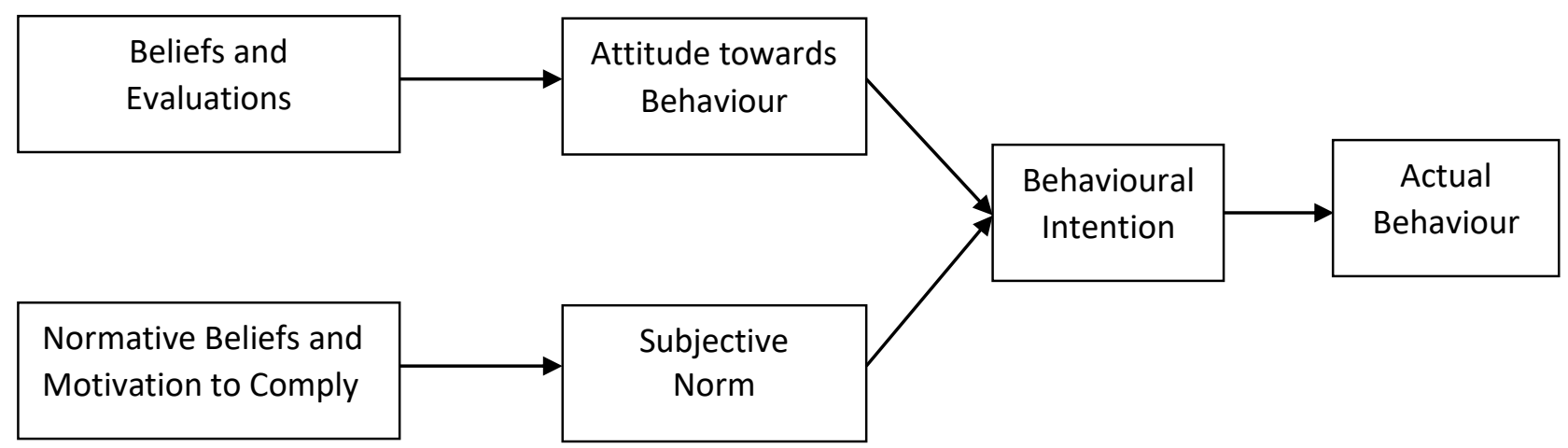

\section{Figure 1: Theory of Reasoned Action}

Source: Davis, F., Bagozzi, R. and Warshaw, R. (1989). User Acceptance of Computer

Technology: A Comparison of Two Theoretical Models. Management Science, 35, 982-1003.

By blending this theory to the context of factors determining increased patronage of shopping malls, it can be reasonably thought of that, the actual behavior on the right tail end of figure 1 represent the increased patronage of shopping malls which is consequent to the shoppers' behavioral intention. The theory avails that the intention or insistence of the shoppers to shop at the malls is predetermined by their preformed attitude and subjective norms which are products of a set of beliefs, evaluations and several external cues including their motivation to comply with their formed mindsets. And in the light of these, this current study therefore views the factors responsible for the increased patronage of shopping malls as being multifaceted. Some shoppers could or might have engaged in such patronage for socialisation reasons while some on exploration and some, because of factors like the customer services or conveniences they enjoy. The distance/location factor could as well be responsible for their increased patronage, but in all, there is still a need to empirically prove that these factors contribute to the 
shoppers' patronage of the malls as opposed to their shopping practices at the traditional marketplaces.

\section{Review of Empirical Studies}

Factors determining shoppers' patronage at shopping malls is now commanding greater research interest even increasingly within the camp of knowledge in retail marketing. Wong et al. (2012) for instance conducted a study in Hong Kong, titled the relationship between Shopping Mall Attributes, Customer Satisfaction and Positive Word-Of-Mouth: China Visitors in Hong Kong. Objectives include examine the influence of five shopping mall attributes (i.e. quality of customer services, convenience, mall environment, quality of retailers and rewards) on customer Satisfaction and to examine the influence of customer satisfaction on positive word-of-mouth recommendation. Questionnaire was employed for data collection, while the sample size comprised 750 shoppers. Structural equation modeling was used in testing hypotheses. Findings reveal that quality of customer services, convenience, mall environment, quality of retailers and rewards are factors that encourage consumers to shop at malls in Hong Kong. The study concludes that listening to customers' demands and resolving their problems are critical to Retaining current customers and promoting positive word-of-mouth recommendation. Shopping mall management should lead from not only the top but also from the front, by showing frontline service staff how to be responsive and energetic in their customer interactions.

Kumar and Thakur (2014) conducted a study in Madhya Pradesh, India, titled A Study of Key Factor Affecting Customer Relationship towards Shopping Mall. Objectives include to identify the various factors that affect shoppers towards shopping malls and to provide managerial implication to improve performance of shopping mall. Exploratory research design was used to perform the study. Sample size of 100 respondents was used and Data was collected through questionnaire. Hypotheses were tested using chi-square statistical tool with the help of SPSS version 16. Findings revealed that the main factors affecting shopping mall patronage have been identified as availability of branded, quality and variety of product, alternative and ease of finding product altogether determine shoppers' patronage in India. The study concludes that Indian retail Industries is in boom and more and more national and international players are interested in the emerging retail market in India, information on consumer relating to factors that affect the shopper maybe useful for retailers targeting Indian markets.

Similar to these, Hira and Rasheed (2012) also conducted a study in Pakistan titled determining the Factors affecting Consumer Loyalty towards Shopping Malls. Objectives are to identify the factors that affect the shoppers' loyalty towards shopping malls and to establish a relationship between consumer loyalty factors and shopping malls performance. A sample of 384 respondents was used for the study. Data was collected through the questionnaire while correlation and regression were used in testing the Hypotheses with the help of SPSS version 16. Findings revealed that determinants of consumer loyalty that mostly affect the consumer purchase behaviors towards shopping malls are environment of the mall, image or in other words reputation of the mall and the most important is the convenience. The study concludes that any 
Development in mall environment and image will moderately enhance the consumer loyalty and to build consumer loyalty a mall need to consider the ease of access for consumers.

Idoko et al. (2017) conducted a study in Nigeria, titled "Predictors and Characterization of Mall Shoppers in A Typical Sub-Saharan African Context: Evidence From Nigeria." The objectives were to explore those factors that characterize those who patronize shopping malls among the emerging mall shopping segment in Nigeria. The sample size for the study was Five hundred and twenty mall shoppers. Exploratory factor analysis and cluster discriminant analyses were used on data collected for the study, whereas structural equation modeling technique was utilized to perform confirmatory factor analysis. Findings clearly identified aesthetic and architectural design, escapism, socio-personality transformation, safety, role enactment, quality products, price consciousness, and presence of reputable global retail stores as key predictors of mall shopping. Multiple discriminant analysis shows that aesthetics and architectural design is the most important factor that distinguishes the segment, followed by escapism, and presence of reputable global retail stores. The study concludes that he emergence of malls in Nigerian retail landscape which culminated in the appearance of mall shopping segment is increasingly redefining shopping channel choice criteria. Hedonic dimensions represented by sociopersonality transformation, aesthetics and architectural design as opposed to quest for utilitarian-focused need satisfaction tend to dominate studied respondents motivations. Arguably, as malls are increasingly being perceived as shoppers" experiential hub and potent force for personality upgrade; marketing managers, mall developers as well as policy makers should carefully incorporate experiential components in mall designs and possibly in modernization of existing traditional retail outlets or in the construction of new open market spaces in order to appeal to the expectations of the emerging shopping needs and remain competitive.

The gap noted in the previous literature which this study tends to fill is that minimal research attention has been directed in this domain to deepen and possibly broaden understanding regarding those factors like distance, convenience, customer services, socialization, and exploration among others that influence shopping mall patronage among shoppers in Enugu metropolis.

\section{Proposed Conceptual Framework for the Study}

Research efforts have been expended on quite some factors that determine shoppers' patronage of malls. Very little has been done on factors like socialisation shopping; exploration; convenience, distance and customer service as they determine shoppers' patronage. Based on this, figure 2 below can be used to describe the hypothesised factors determining shoppers' patronage of malls in Enugu metropolis. 


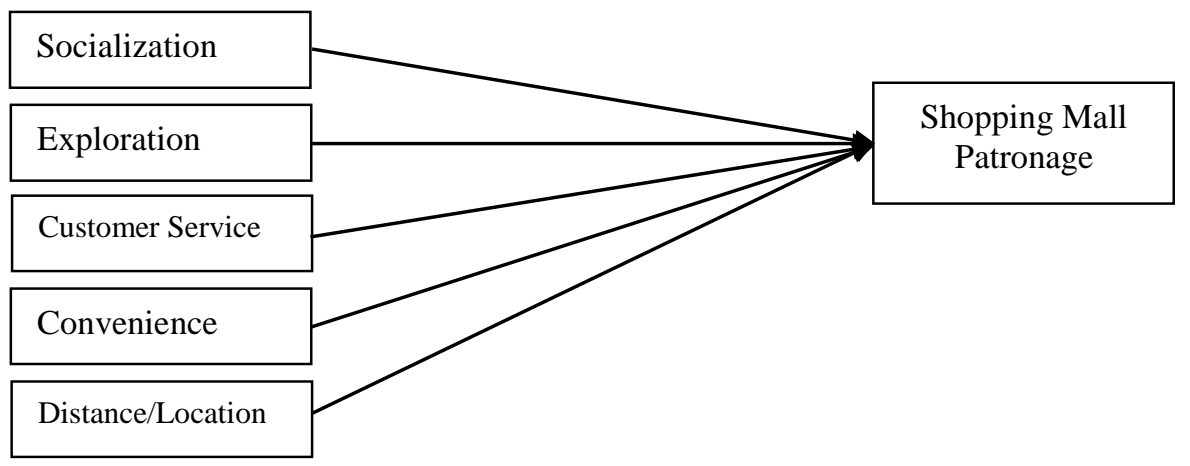

Fig. 2: Proposed Conceptual Framework

Source: Researcher's Illustration

Figure 2 above presents the proposed conceptual framework showing the hypothesised factors determining the shopping mall patronage in Enugu metropolis. The drivers of each construct as captured in the literature include:

\section{Distance}

a. Short Distance Location

b. Distance is Trekkable and Enjoyable

c. Not Stressful to Access

\section{Convenience}

a. Good Parking Space

b. Easy to Access Everyday

c. Toilets Available in case of Emergency
3. Customer Service

a. Reliability

b. Empathy

c. Responsiveness

\section{Exploration}

a. Like to Find New Things

b. Wanting to Meet New Friends

c. Seeking Funs
4. Socialization

a. Shopping with Friends

b. Shopping for Recreational Purpose

c. Vacation/Holiday Trip

a. Patronage Frequency

b. Loyal to the Shopping Mall

c. The share of Wallet Spent

\section{Methodology}

Survey research design was adopted for this study. The study was carried out in Enugu metropolis. While there are many shopping malls in the State, the study concentrated only on the two most popular ones such as Polo Park Mall and Enugu Shopping Mall. The population of the study comprises only the customers that visit these malls, and of course, these are not readily known. The approach adopted for determining the required sample size was by using the Topman's formula for the unknown population as opined by Nwbuokei (1986). The formula is specified as thus;

Where $\mathrm{n}=$ sample size

$$
n=\frac{Z^{2} P Q}{e^{2}}
$$


$Z$ = confidence level (1.96) Constant

$\mathrm{P}=$ proportion of positive response

$\mathrm{Q}=$ proportion of negative response

e = Tolerable Error margin

In a preliminary pilot survey conducted with the customers visiting the two shopping malls, 40 copies of questionnaire (20 each) were administered to the shoppers in each shopping mall with the aim of determining beforehand, the behavior of the respondents when they are eventually used for the actual survey. From Polo Park Shopping Mall, 16 copies were returned,andfour others were not. These give an idea that there is a probability of getting a success response $(p=$ $0.80)$ from Polo Park Shopping Mall and a probability of getting failure response $(q=0.20)$ from them.

At the Enugu Shopping Mall, out of the 20 copies of a questionnaire administered to them, 13 copies were returned which gives an idea that there is a chance of getting a positive response from them by $65 \%$ and a failure response by $35 \%$.

Using these to compute the sample size from the unknown population groups using $95 \%$ confidence level and $5 \%$ tolerable error margin.

\section{Required Sample Size from Polo Park Mall (SHOPRITE)}

$$
n=\frac{1.96^{2} \times 0.80 \times 0.20}{0.05^{2}}=\frac{3.8416 \times 0.80 \times 0.20}{0.0025}=\frac{0.614656}{0.0025}=245.8624 \approx 246
$$

\section{Required Sample Size from Enugu Shopping Mall (SPAR)}

$$
n=\frac{1.96^{2} \times 0.65 \times 0.35}{0.05^{2}}=\frac{3.8416 \times 0.65 \times 0.35}{0.0025}=\frac{0.873964}{0.0025}=349.5856 \approx 350
$$

From the above computations, the required sample size of customers used for this study is 246 for Polo Park Mall, and 350 for Enugu Shopping Mall. Altogether, 596 customers would be required as the sample size for this study.

Convenience sampling technique was adopted for capturing these customers. Primary data was required for the study and was gathered using a well-structured questionnaire worded on a fivepoint Likert scale. The validity and reliability of the questionnaire were determined by using discriminant validity and composite reliability methods. The datasets gathered were analysed using Structural Equation Modeling through Amos version 25.0 with maximum likelihood estimation.

\section{Results and Discussion}

Out of the 596 customers captured in the survey, 107 of them did not return the copies of the questionnaire served to them. 489 others returned theirs. Out of these returned copies, 51 were discovered not fully completed. Altogether, the copies of the questionnaire that were used for the analysis are 438 , finding percentage success response rate of $73.49 \%$.

Table 1 below presents the demographic profile and descriptive statistics. 
INTERNATIONAL JOURNAL OF ACADEMIC RESEARCH IN BUSINESS AND SOCIAL SCIENCES

Vol. 9, No. 11, November, 2019, E-ISSN: 2222-6990 ㄷ 2019 HRMARS

Table 1: Demographic Profile and Sample Descriptive Statistics

\begin{tabular}{|c|c|c|c|c|c|}
\hline & Frequency & Percentage & & Frequency & Percentage \\
\hline Gender & & & Age & & \\
\hline Male & 186 & $42.5 \%$ & $\geq 45 y r s$ & 44 & $10.0 \%$ \\
\hline Female & 252 & $57.5 \%$ & $35-44 y r s$ & 56 & $12.8 \%$ \\
\hline \multirow[t]{2}{*}{ Total } & 438 & $100.0 \%$ & $25-34 y r s$ & 226 & $51.6 \%$ \\
\hline & & & $<25 y r s$ & 112 & $25.6 \%$ \\
\hline Marital Status & & & Total & 438 & $100.0 \%$ \\
\hline Married & 211 & $48.2 \%$ & & & \\
\hline Single & 227 & $51.8 \%$ & & & \\
\hline \multirow[t]{8}{*}{ Total } & 438 & $100.0 \%$ & \multicolumn{3}{|c|}{ Total Income Status ( '000 - '999) } \\
\hline & & & $\geq N 150$ & 87 & $19.9 \%$ \\
\hline & & & N100 - & 135 & $30.8 \%$ \\
\hline & & & N149 & & \\
\hline & & & N75 - N99 & 102 & $23.3 \%$ \\
\hline & & & N50 - N74 & 63 & $14.4 \%$ \\
\hline & & & $\mathrm{N} 25-\mathrm{N} 49$ & 51 & $11.6 \%$ \\
\hline & & & Total & 438 & $100.0 \%$ \\
\hline
\end{tabular}

Field Research Survey, 2018

\section{Test of Hypotheses}

Datasets were analysed by using Structural Equation Modeling (SEM). The test was run on AMOS version 25.0 with maximum likelihood estimation.

Table 2: Correlations, Mean, Standard Deviation, and Square Root of AVE

\begin{tabular}{|c|c|c|c|c|c|c|}
\hline Constructs & SMP & Distance & Convenience & Customer Service & Socialization & Exploration \\
\hline SMP & .911 & & & & & \\
\hline Dist. & .074 & .879 & & & & \\
\hline Con. & $.729 *$ & $.816^{*}$ & .905 & & & \\
\hline CS & .110 & $.623 * *$ & .217 & .936 & & \\
\hline Soc. & $.508 * *$ & $.403^{*}$ & $.619 * *$ & $.429 *$ & .924 & \\
\hline Expl. & $.904^{* *}$ & $.309 * *$ & $.460 * *$ & $.322 * *$ & $.551^{*}$ & .930 \\
\hline Mean & 4.37 & 4.25 & 2.03 & 4.33 & 3.92 & 4.19 \\
\hline Std Dev. & 6927 & .7355 & .1123 & .5921 & .9763 & .5882 \\
\hline
\end{tabular}

${ }^{*} p<0.05,{ }^{* *} p<0.01$

Table 2 above presents the mean, standard deviation, correlation and square root of the average variance extracted (AVE). Convenience, socialization and exploration had a significant positive 
correlation with shopping mall patronage whereas distance and customer service had no significant correlation with Shopping Mall Patronage.

Table 3: Factor loading $(\lambda)$, Cronbach's $(\alpha)$, AVE and Composite Reliability

\begin{tabular}{|c|c|c|c|c|c|c|}
\hline Constructs & Items & $\lambda$ & Cronbach's $\boldsymbol{\alpha}$ & AVE & S.R of AVE & Composite Reliability \\
\hline \multirow[t]{3}{*}{ S/Mall Patronage } & PF & .821 & \multirow[t]{3}{*}{.837} & \multirow[t]{3}{*}{.811} & \multirow[t]{3}{*}{.911} & \multirow[t]{3}{*}{.803} \\
\hline & Loyal & .744 & & & & \\
\hline & SWS & .759 & & & & \\
\hline \multirow[t]{3}{*}{ Distance } & SDL & .033 & \multirow[t]{3}{*}{.709} & \multirow[t]{3}{*}{.724} & \multirow[t]{3}{*}{.879} & \multirow[t]{3}{*}{.836} \\
\hline & $T \& E$ & .215 & & & & \\
\hline & NS & 0.07 & & & & \\
\hline \multirow[t]{3}{*}{ Convenience } & VG & .842 & \multirow[t]{3}{*}{.864} & \multirow[t]{3}{*}{.931} & \multirow[t]{3}{*}{.905} & \multirow[t]{3}{*}{.845} \\
\hline & EA & .723 & & & & \\
\hline & TA & .801 & & & & \\
\hline \multirow[t]{3}{*}{ Customer Service } & Rel. & .166 & \multirow[t]{3}{*}{.855} & \multirow[t]{3}{*}{.826} & \multirow[t]{3}{*}{.936} & \multirow[t]{3}{*}{.916} \\
\hline & Emp. & .013 & & & & \\
\hline & Resp. & .147 & & & & \\
\hline \multirow[t]{3}{*}{ Socialization } & SwF & .772 & \multirow[t]{3}{*}{.872} & \multirow[t]{3}{*}{.849} & \multirow[t]{3}{*}{.924} & \multirow[t]{3}{*}{.867} \\
\hline & $\mathrm{RS}$ & .818 & & & & \\
\hline & $\mathrm{V} / \mathrm{H}$ & .748 & & & & \\
\hline \multirow[t]{3}{*}{ Exploration } & FNt & .767 & \multirow[t]{3}{*}{.913} & \multirow[t]{3}{*}{.903} & \multirow[t]{3}{*}{.930} & \multirow[t]{3}{*}{.881} \\
\hline & MNF & .981 & & & & \\
\hline & SF & .766 & & & & \\
\hline
\end{tabular}

Two measures were employed for ascertaining the reliability of the constructs used in this study. The first measure examined the factor loading for each indicator of each construct measured. The result of the factor loadings is presented in Table 3 above. Except for the indicators for distance and Customer Service which were not significant, at $5 \%$ level of significance with the corresponding t-values to all the indicators of other constructs which are greater than 2, each indicator has a significant factor loading. The second measure is Cronbach's $\alpha$. It measures the internal consistency of the scales/items used for each indicator on the questionnaire. According to Bernstein and Nunnally (1994), the minimum cut off value for Cronbach's $\alpha$ is 0.7 . Hence as presented on the table above, the Cronbach's $\alpha$ for each construct varies from 0.709 to 0.913 which shows that the scales/items are internally consistent hence, the response scores collectable with the test instrument are reliable.

The composite reliability (CR) measures the degree to which each construct's indicators represent or explain the latent construct. The value of composite reliability for each construct varies from 0.803 to 0.916 . Therefore, to confirm the validity of all the constructs, both Convergent and discriminant validity methods were assessed. Also, the Average Variance Extracted (AVE), which measures the amount of variance captured by the constructs through the 
indicators in comparison with the amount of variance captured due to the measurement error was calculated.

To evaluate the discriminant validity, the square root of AVE must be greater than the inter-item correlations among constructs. From tables 2 and 3 above, it can be obtained that the square root of AVE is greater than the inter-item correlations. Therefore, the discriminant validity of all the scales was supported.

To evaluate the convergent validity of the scales, Bagozzi and Yi (1988) opine that the value of AVE should be greater than 0.5. From Table 2 and 3 above, it can be seen that the values of AVE vary from 0.879 to 0.936 which are greater than 0.5 . With these being authenticated, the composite reliability and the value of Cronbach's $\alpha$ for all the indicators were accepted. Thus, the test instrument is valid and sufficient to generate reliable responses.

\section{Result of Structural Equation Model}

The structural equation model was run through AMOS version 25.0 using maximum likelihood estimate (MLE). The constructs included in the model included: Shopping Mall Patronage (three items scale), Distance (three items scale), Convenience (three items scale), Customer Service (three items scale), Socialization (three items scale), and Exploration (three items scale). The resulting model produced good fit indices: $\boldsymbol{\chi}^{2}=224.101$, degrees of freedom (df) $=117, p>0.05$. This is insignificant, yet it shows that the model is fit (Barrett, 2007). Comparative Fit Index (CFI) $=0.977$ which is greater than the recommended value of 0.95 ( $\mathrm{Hu}$ and Bentler, 1999); Goodnessof-Fit Index $(\mathrm{GFI})=0.903$ which is slightly greater than the recommended value of 0.90; Adjusted Goodness-of-Fit Index (AGFI) $=0.91$ which is close to the omnibus cut off point of 0.95, Root Mean Square Error of Approximation (RMSEA) $=0.074$. As presented in the table below, Convenience was positively and significantly related to Shopping Mall Patronage $(B=.662, p<$ $0.05)$, Socialization $(B=.203, p<0.05)$ was positively and significantly related to Shopping Mall Patronage; and lastly Exploration $(B=.417, p<0.05)$ was positively and significantly related to Shopping Mall Patronage. However, Distance was not significantly related to Shopping Mall Patronage $(b=.026, p>0.05)$ likewise Customer Service not significantly related to Shopping Mall Patronage $(B=.004, p>0.05)$.

Table 4: Structured Equation Model Result

\begin{tabular}{lccr}
\hline Path Description & Hypothesis & $\begin{array}{c}\text { Unstandardized } \\
\text { Path Estimates }\end{array}$ & Remarks \\
\hline Distance => Shopping Mall Patronage & & .026 & $\mathrm{NS}$ \\
Convenience => Shopping Mall Patronage & $\mathrm{H}_{1}$ & $.662^{* *}$ & $\mathrm{~S}$ \\
& $\mathrm{H}_{2}$ & & $\mathrm{NS}$ \\
Customer Service => Shopping Mall Patronage & $\mathrm{H}_{3}$ & .004 & $\mathrm{~S}$ \\
Socialization => Shopping Mall Patronage & $\mathrm{H}_{4}$ & $.203^{* *}$ & $\mathrm{~S}$ \\
& & & $.417^{* *}$ \\
Exploration => Shopping Mall Patronage & $\mathrm{H}_{5}$ & & \\
\hline
\end{tabular}




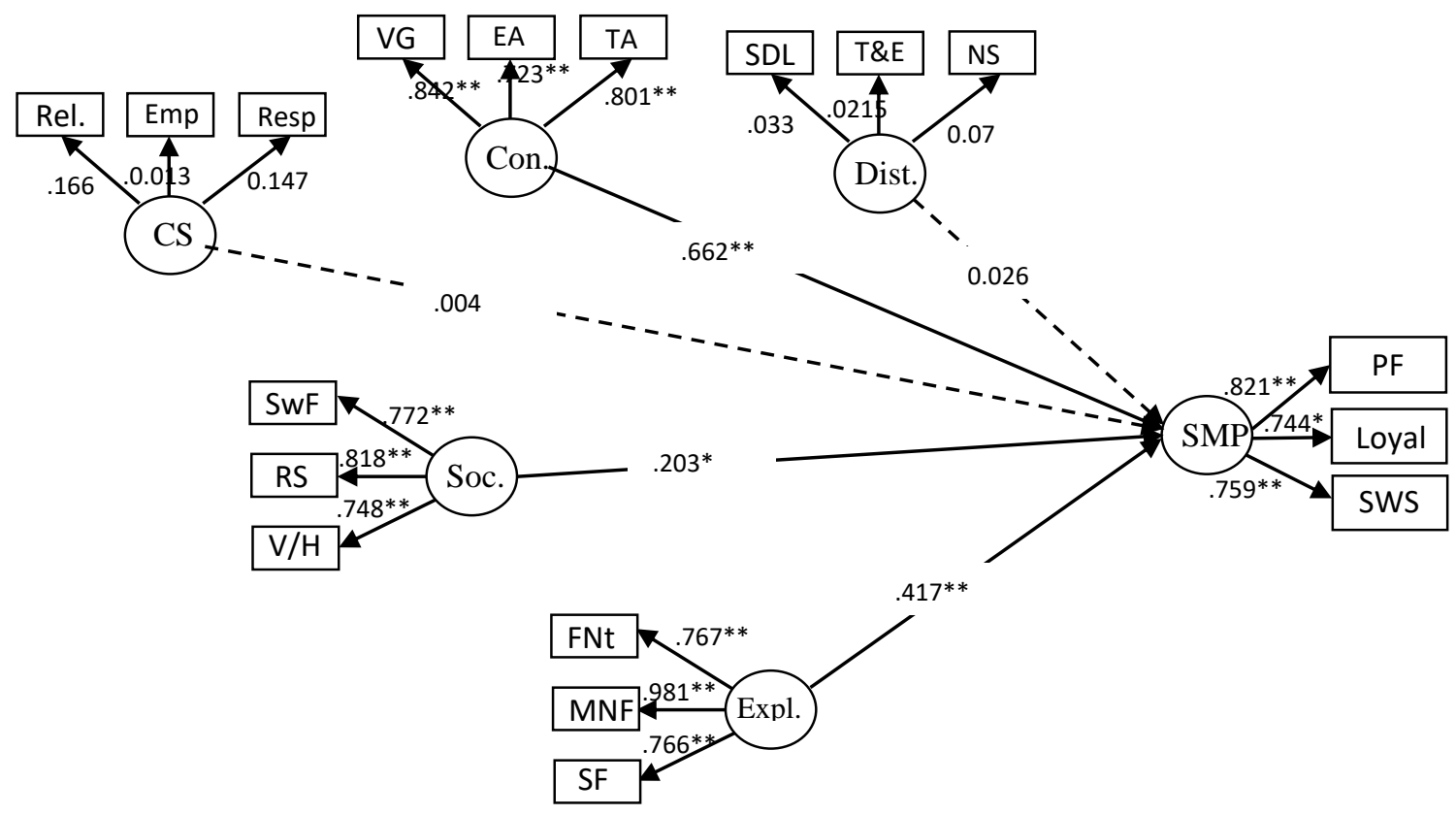

\section{Discussion of Findings}

This study was premised on determinants of shoppers' patronage in Enugu metropolis, Enugu state Nigeria. By covering the two major shopping malls in the State, findings from the study showed that;

1. Distance does not have a significant influence on shoppers' patronage of shopping malls in Enugu metropolis. This finding is in line with the finding of Hansen and Solgaard (2004) that the negative effect of distance on store choice behavior was remarkably larger when store choice behavior was measured as frequency than when store choice behavior was measured as budget share.

2. Convenience has a significant influence on shoppers' patronage of shopping malls in Enugu metropolis; this finding is in line with that of Ahmad (2012) who found out that aesthetic, convenience and accessibility, product variety, entertainment, and service quality, had a positive effect on Saudi shopping mall shoppers, this also agrees with the findings of Anselmsson (2006) that convenience (comprising trading hours) served as the third most important influence over satisfaction and the fifth largest influence over mall-visit frequency. Hence, trading hours appear to exert a salient influence over patronage behavior.

3. Customer Service does not have a significant influence on shoppers' patronage of shopping malls in Enugu metropolis;

4. Socialization has a significant influence on shoppers' patronage of shopping malls in Enugu metropolis, the finding is in line with the findings of (Makgopa, 2016) which states that consumers visit shopping malls for entertainment purposes such as watching movies, celebrating 
special occasions, and for eating out and not for just buying groceries, home ware, and the use of mall facilities such as cash withdrawals and paying at automated teller machines (ATM).

5. Exploration has a significant influence on shoppers' patronage of shopping malls in Enugu metropolis. This finding is in line with the finding of Telci (2013) which states that shopping malls are now characterized as venues that provide a comfortable shopping experience and have turned into social centers and entertaining facilities for various activities.

\section{Conclusion and Recommendation}

Idoko et al. (2017) did a work on predictors and characterization of mall shoppers with specific highlight on "aesthetic and architectural design, escapism, socio-personality transformation, safety, role enactment, quality products, price consciousness, and presence of reputable global retail stores" as key predictors of mall shopping. However, this study took a different dimension as it showcased distance, customer service, convenience, socialization and exploration as motivations behind shopping in modern malls from Nigerian perspective. Distance and customer service are not the major factors that stimulate shoppers' patronage. Convenience (in terms of easy access to the mall, good parking space, clean toilet); socialization (in terms of recreational shopping, shopping with friends; and going on vacation or holiday trip at the mall); and lastly exploration (in terms of finding new things at the mall, wanting to meet new friends, and seeking fun) are major factors determining shoppers' patronage in Enugu metropolis. It is therefore recommended that the management of the shopping malls should direct their resources toward constant improvement of the mall facilities that attract shoppers to the mall.

\section{References}

Abrams, R. (2008). USA Today.

Ahmad, A. M. K. (2012). Attractiveness factors influencing shoppers' satisfaction, loyalty, and word of mouth: An empirical investigation of Saudi Arabia shopping malls International Journal of Business Administration 3(6), 101-112.

Anselmsson, J. (2006). Sources of customer satisfaction with shopping malls: A comparative study of different customer segments. The International Review of Retail Distribution and Consumer Research, 16(1), 115-138.

Ajzen, I., \& Fishbein, M. (1980). Understanding attitudes and predicting social behavior, Engelwood Clifts, NJ: Prentice-Hall. .

Asamoah, G. (2012). Factors which influence the buying behaviors' of customers with multiple regular customer cards. Bachelor Thesis.

Babin, B. J. (1994). Measuring hedonic and utilitarian shopping value. Journal of ConsumerResearch, 20(4), 644-656.

Berry, L., Kathleen, S. \& Dhruv. (2002). Understanding service convenience, Journal of Marketing, 66, 1-17.

Berry, L. L. (2001). Harvard business review on customer relationship management, USA: Harvard Business School Publishing Corporation. 
INTERNATIONAL JOURNAL OF ACADEMIC RESEARCH IN BUSINESS AND SOCIAL SCIENCES

Vol. 9, No. 11, November, 2019, E-ISSN: 2222-6990 @ 2019 HRMARS

Chang, E., \& Luan, B., (2010).Chinese consumers' perception of hypermarket store image. Asia Pacific Journal of Marketing and Logistics, 22 (4), 512-527.

Deci, E. L., \& Ryan, R. M. (2002). Handbook of self-determination research, New York: University of Rochester Press.

Farris, P. W., Neil, T. B., Philip, E. P., \& David, J. R. (2010). Marketing metrics: The definitive guide to measuring marketing performance New Jersey: Pearson Education Inc.

Fishbein, M., \& Ajzen, I. (1975). Belief, Attitude, Intention and Behavior: An Introduction to the Theory and Research. Reading, MA: Addison-Wesley.

Ghaddar, S., \& Brown, C. (2005). The cross-border Mexican shopper: A profile, Research Review $12(2), 46-50$.

Graham E. (1988). The call of the mall, Wall St J. 7R.

Handy, S. L., \&Clifton, K. J. (2001). Local shopping as a strategy for reducing automobile travel. Transportation, (28), 317-346.

Hansen, T., \& Solgaard, H. S. (2004). Measuring the effect of distance on consumer patronage behavior: A structural equation model and empirical results, new perspectives on retailing and store patronage behavior: A study of the Interface between retailers and consumers Boston: Kluwer Academic Publishers.

Hansen, R., \& Deutscher, T. (1978). An empirical investigation of attribute importance in retail store selection. Journal of Retailing, 53(4): 59- 95.

Hassan, Y., Muhammad, N. M. N., \& Bakar, H. A. (2010).Influence of shopping orientation and store image on patronage of furniture store International Journal of Marketing Studies, 2(1), 175-184.

Heffner, K., \& Twardzik, M. T. (2014). Shopping malls and its social impact on the outer metropolitan zones (The Example of the Silesian Voivodeship).5th Central European Conference in Regional Science - CERS.

Hira F., \& Rasheed, M. (2012). Determining the factors affecting consumer loyalty towards shopping mall. Global Advanced Research Journal of Management and Business Studies, 1(4), 134-140.

Idoko, E. C., \& Nebo, G. N. (2017).Mall consumption motivations in Nigeria: the mediating role of attitude among shoppers. Journal of Business Science, 1(2), 13-41.

Idoko, E. C., Nkamnebe, D. A., \& Okoye, V. I. (2017).Predictors and characterization of mall shoppers in a typical Sub-Saharan African context: Evidence from Nigeria. Indian Journal of Commerce and Management Studies VIII (1), 1-15.

Iliyasu, A. D. (2011). Proposed shopping mall, millennium city Kaduna: Integrating shopping and recreation facilities Master's Thesis. Nigeria: Ahmadu Bello University, Zaria.

Jobber, D. (2001). Principles and practice of marketing. England: McGraw-Hill Publishing Company.

Kasnaeny, K., Sudiro A, Hadiwidjojo, D., \& Rohman, F. (2013). Patronage buying motives of coffee shop's consumers Journal of Business and Management (IOSR-JBM)8(3).

Kaufman, C. F. (1996). A new look at one- stop shopping: A times model approach to matching store hours and shopper schedules, Journal of Consumer Marketing13(1),4-52. 
Kim, M. K., Park, M. C., \& Jeong D. H. (2004). The effects of customer satisfaction and switching barrier on customer loyalty in korean mobile telecommunication services, Electronics and Telecommunications Research Institute, School of Business Information and Communication, University, South Korea.

Kotler, P., \& Armstrong, G. (2004). Principles of marketing, New Jersey: Pearson Education.

Kumar, A., \& Thakur, Y.S. (2014). A study of key factor affecting customer relationship towards shopping mall/nternational Journal of Business Quantitative Economics and Applied Management Research1(4).

Loudon, D. L. \& Bitta, A. J. D. (1993). Consumer behavior: Concepts and application, 4th ed. NewYork: McGraw- Hill.

Makgopa, S. (2016). Determining consumers' reasons for visiting shopping malls, Innovative Marketing, 12 (2).

Manana, Z. (2009). Antecedents of store patronage and cross shopping: the case of increasing grocery spend in Soweto, Master's Thesis. South Africa: University of Pretoria.

Mathwick, C., Malhotra, N., \& Rigdon, E. (2001). Experiential value: Conceptualization, measurement and application in the catalogue and internet shopping environment. Journal of Retailing 77, (1), 39-56.

Mohamad, M. Y., Al Katheeri, F., \& Salam, A. (2015).A GIS application for location selection and customers' preferences for shopping malls in Al Ain City; UAE. American Journal of Geographic Information System, 4(2), 76-86.

Muange, J. N. (2014). An investigation into the impact of increased development of shopping malls on the Kenyan residential real estate market case study: The junction shopping Mall Diploma Thesis. College of Architecture and Engineering University of Nairobi.

$\mathrm{Ng}$, C. F. (2003). Satisfying shoppers psychological needs: from public markets to cyber mall. Journal of Environmental Psychology, (23), 439-455.

Nwabuokei, P. (1986).Fundamentals of statistics. Enugu: Koruna Publications.

Abratt, J. M., \& Dion, P. (2006). The Influence of Retailer Reputation on Store Patronage. Journal of Retailing and Consumer Services, (13), 221-230.

Paswan, A., Pineda, M. D. S., \& Ramirez, F. C. S. (2010). Small vs. large retail stores in an emerging market - MexicoJournal of Business Research (63), 667-672.

Reimers, V., and Clulow, V. (2009). Retail centers: It's time to make them convenient', International Journal of Retail and Distribution Management: Incorporating Retail Insights, 37(7), 541-562.

Rousseau, G. G., and Venter, D. J. L. (2014). Mall shopping Preferences and Patronage of Mature Shoppers. Journal of Industrial Psychology, 40(1), 1-12.

Rupesh, K. T., \& Anish, A. (2010). Understanding the consumer behavior towards shopping malls in Raipur City. International Journal of Management and Strategy 1(1).

Rust, T. R., \& Anthony, J. Z. (1993). Customer satisfaction, customer retention, and market share. Journal of Retailing, 201-211.

Tauber, E.M. (1972).Why do people shop? Journal of Marketing, (36), 9-46. 
Telci, E. E. (2013). High shopping mall patronage: Is there a dark side? Quality and quantity, 47(5), 2517-2528.

Tiwari, R. K., \& Abraham, A. (2010).Understanding the consumer behavior towards shopping malls in Raipur City. International Journal of Management and Strategy, 1(1).

Thang, D. C. L., \& Tan, B. L. B. (2003). Linking consumer perception to preference of retail store: An empirical assessment of the multi attribute store image. Journal of Retailing and Consumer Services, 10(4), 193-200.

Tosun, C., Temizkan, S. P., Timothy, D., \& Fyall, A. (2007). Tourist shopping experiences and satisfaction. International Journal of Tourism Research, 9, 87-102.

Wai, C. K. (2009). A Study of Marketing Strategy of Shopping Centre for Customer Retention in Hong Kong. 